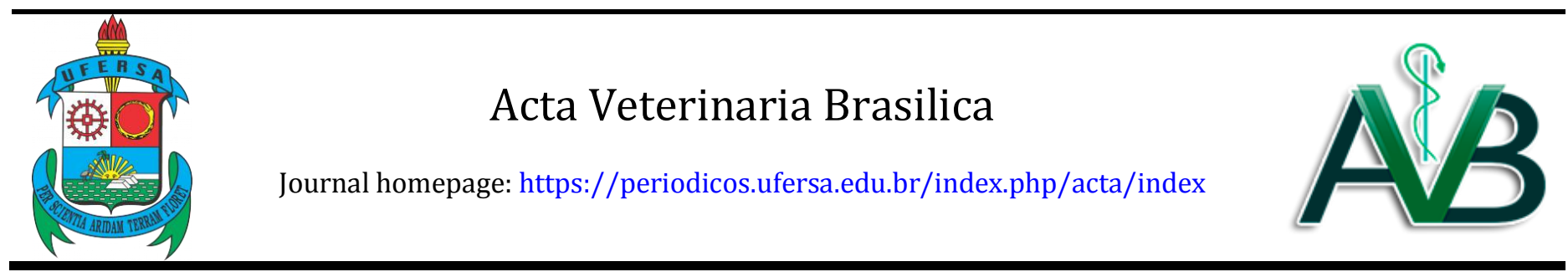

Original Article

\title{
Morphology and biometry of the thymus in Gallus gallus domesticus (Linnaeus, 1758) from the isa brow lineage
}

\author{
Cheston Cesar Honorato Pereira1, Adriana Garcia de Freitas ${ }^{2}$, Marina Carla da Silva ${ }^{3}$, Tiago Luis Eilers Treichel ${ }^{4}$, \\ Kênia Cristina Calábria ${ }^{5}$, Milla de Moraes ${ }^{6}$
}

1 Professor Titular da Universidade de Rio Verde/Faculdade de Medicina Veterinária.

2 Professora adjunto do Instituto Federal do Triângulo Mineiro/ Faculdade de Zootecnia.

${ }^{3}$ Aluna de graduação da Universidade Federal de Uberlândia/ Faculdade de Medicina Veterinária.

${ }_{4}^{4}$ Professor Adjunto I da Universidade de Rio Verde/ Faculdade de Medicina Veterinária.

${ }^{5}$ Professora da Fundação Presidente Antônio Carlos/Faculdade de Medicina Veterinária.

${ }^{6}$ Aluna de Graduação da Universidade de Rio Verde/Faculdade de Medicina Veterinária.

\section{A R T I C L E I N F O}

\section{Article history}

Received 31 August 2017

Received in revised form 20 October 2017

Accepted 24 October 2017

\section{Keywords:}

Anatomy

Glands

Gallinaceous

Lymphoid tissue

\begin{abstract}
A B S T R A C T
The thymus was described in thirty chickens of the Isa Brow line. Samples were prepared by fixation in $10 \%$ formalin solution and analyzed by subsequent dissection. The thymus lobes were found along the ventral region of the neck from the third cervical vertebra to the proximity to the clavicular bones in relation to the vagus nerve, the common artery of the vagus nerve and the jugular vein. The number of lobes ranged from four or five to the right antimere and three to five to the left. The mean lobe size was $0.80 \times 0.43 \times 0.38 \mathrm{~cm}$ for the cranial lobe, $1.53 \times 0.81 \times 0.42 \mathrm{~cm}$ for the middle cranial lobe, $2.10 \times 0.64 \times 0.46$ for the middle lobe, $2.29 \times 0.89 \times 0.59$ for the middle caudal lobe and $3.82 \times 1.39 \times 1.11 \mathrm{~cm}$ for the caudal lobe in the right antimere. In the left antimere, $0.80 \times 0.41 \times 0.37 \mathrm{~cm}$ was recorded for the cranial lobe, $1.55 \times 0.80$ $\mathrm{x} 0.44 \mathrm{~cm}$ for the middle cranial lobe, $2.37 \times 0.87 \times 0.56$ for the middle lobe, $2.37 \times 0.85$ x 0.60 for the middle caudal lobe and $3.89 \times 1.43 \times 1.08 \mathrm{~cm}$ for the caudal lobe. The thymus of birds from the Isa Brow lineage presented characteristics similar to those found in other lineages with respect to the division of lobes and topography. However, skeletal, syntopic and holotopic disparities were observed that indicate some unique characteristics of the thymus in this lineage.
\end{abstract}

\section{INTRODUCTION}

According to Mendes; Moreira (2005), the first batch of chickens imported in the 1960s initiated the poultry industry in Brazil. Pereira et al. (2016) point out that genetic selection through zootechnical exploitation of birds generated individuals that were better adapted to for various agricultural purposes, which generated changes in the organ morphology of current species compared to the original strains.

According to Marín; Nava; Mavárez (2004) morphometric and morphological features such as the size and location of lymphoid organs can be used as references for the evaluation of individual immunocompetence, and the development and size of the thymus can be used as indicators of the general health status of the birds. According to Hohn (1947), the thymus of domestic ducks and geese presents features more similar to those of the original wild species in which few lobes occur (i.e., usually 5), with the cranial lobe being larger than the previous lobes. The same author in 1961 also indicated that thymus involution occurs during sexual maturity, but that increased thymic parenchyma size is observed for a few weeks after the

\footnotetext{
*Corresponding author: cheston@bol.com.br
} 
first and sometimes the last sexual cycle. There is also usually some evidence of involution due to stress.

Schwarze; Schröder (1972), Nickel; Schummer; Seiferle(1977), Kendall (1980), Getty (1986) and Baumel (1993) in a description of the thymus of the Gallinaceae reported that the thymus appears as a paired, vascularized and enlarged organ extending along the neck and in intimate relation to the jugular vein and vagus nerve without division of the lobes in young birds. Getty (1986) added that the thyroid gland is located near the more caudal thymus lobe and can penetrate the thymus tissue.

Schwarze; Schröder (1972) and Getty (1986) reported three to eight lobes in chickens while Nickel; Schummer; Seiferle (1977), reported six to eight, highlighting the difference in size between the thymic lobes. Kendall (1980) likewise describes seven lobes for each antimere and reported no significant differences in size between antimeres. Santana et al. (2000) observed three to six lobes in the right antimere and two to nine lobes in the left in birds of the Avian Farms lineage.

Silva et al. (2001), after analysis of 30 birds from the Label Rouge strain, found two to six lobes in the right antimere; $6.66 \%$ had two or six lobes, $23.33 \%$ had four lobes, $30 \%$ had three lobes, and $33.33 \%$ had five lobes. In the left antimere, the same authors found one to five lobes; in $10 \%$ of the observations five lobes were found, $16.66 \%$ had four lobes, $20 \%$ had two, and $26.66 \%$ had one or three lobes. The authors also emphasized that the thymus was sometimes connected to the thyroid gland through the caudal lobe, which occurred in 4 of the analyzed birds.

Santana et al. (2001) described the thymic lobes in 30 hens of the NPK strain, which ranged in number from one to seven and three to seven in the right and left antimeres, respectively. The lobes were observed in the cervical region and were arranged laterally to the neck in each antimere. Thymic thoracoabdominal lobes were rare and found in only three birds, always in the left antimere.

Lima; Santana; Dos Reis (2004) reported after analysis of the thymus morphology in ducks (Anas platyrhynchos) that the organ consists of chains of lobes (right and left) located along the middle third of the vascular-nerve plexus of the neck, presenting an irregular contour with a mean of 11.5 lobes per antimer. They pointed out that the higher the number of lobes, the smaller the length, width, and thickness of the organ. Describing the thymus of the curassow species Crax fasciolata, Santana et al. (2004) describe the position of the dorsolateral thymus to the vascular-nerve plexus of the neck. The lobes were irregularly shaped, and the mean number of lobes per antimere was six.
Santana et al. (2007), analyzing the thymus from Angola chickens (Numidea meleagris galeata), found the presence of cervical thymic lobes in both antimeres in the ventral-cervical region dorsolateral to the vascularnervous bundle. The number of lobes ranged from seven to 22, with a higher frequency of occurrence of seven and six lobes for the right and left antimere, respectively. They also found an average length of 1.12 and $1.27 \mathrm{~cm}$ for the right and left antimere, respectively, and a mean width of 0.30 and $0.34 \mathrm{~cm}$, respectively.

For the Hubbard broiler strain, Pereira et al. (2008) describe four to 13 lobes for the right antimere and three to 11 for the left. The skeletal position of the thymus was described as initiating from the first cervical vertebra to the limit of the thoracoabdominal cavity and in intimate association with the jugular vein and vagus nerve. Birck et al. (2008), working with chickens from the Cobb 500 strain, found chains of thymic lobes parallel to the vascular-nervous bundle and ranging from three to five in number, with 3 lobes most commonly occurring in the left antimere.

Miranda et al. (2008), when analyzing the thymus of Gallus gallus domesticus from the Bovans goldline found that the thymic lobes were arranged linearly and parallel along the cervical-ventral and lateral regions and associated with the common artery of the vagus nerve and jugular vein, varying from two to six lobes for each antimere with variable shapes and sizes.

Santana et al. (2008), describing the thymus in birds from the Paraíso Pedrês strain established that the number of lobes varied from three to eight and two to 10 lobes for the right and left antimere, respectively. Describing the skeletal system, they observed that the organ is located in the craniocaudal direction from the mandible to the clavicular bones, always in the cervical region and dorsolateral to the vascular-nervous bundle.

Gallinaceae of the Gray Master Plumé strain were described by Lima et al. (2009), who reported the thymus location in the cervical and thoracic regions, with the number of lobes ranging from five to 11 and from four to nine for the left and right antimeres, respectively, and presenting variable forms.

In hens (Gallus galllus), Arantes et al. (2011) concluded that the thymic lobes in the cervical region in both antimeres are disposed dorsolaterally to the vascularnervous bundle and that the number of lobes ranged from nine to 15 , with five to eight lobes for the right antimere and four to seven for the left.

In the domestic mallard Anas platyrhynchos, the thymic lobes are present in the cervical region and are arranged in lateral chains in both antimeres, presenting intimate relationships with the vague nerve, the jugular vein and the common arteries of the vagus nerves, presenting 
various forms and sizes but reduced in size in some specimens. This species presents three to five lobes in the right antimere and two to five in the left (RESENDE et al., 2012).

Vianna et al. (2012), investigating 28 Gallus gallus domesticus of the Red Bro Cou Nu line, described two to 11 thymic lobes in the right antimere, with eight lobes being most common, and one to eight thymic lobes in the left antimere with five lobes being most common.

Lima et al. (2013) analyzing 19 specimens of macaws of three different genera, 12 Ara arauna, 5 Ara chloropterus and 2 Anodorhynchus hyacinthinus, found no cervical lobes in two cases (10.5\%) and no coelomic lobes in 11 (57.9\%). In all specimens and irrespective of the location found, the lobes presented elongated (52.6\% of cases), rounded $(21.1 \%)$ and oval $(15.8 \%)$ forms. The authors reported an average number of 5 lobes per antimere with an average size of $0.49 \mathrm{~cm}$ in length, $0.12 \mathrm{~cm}$ in width, and $0.05 \mathrm{~cm}$ thickness.

Pereira et al. (2016) studied thymic anatomy in 30 ostrich pups (13 males and 17 females) aged 10 to 20 days and reported that the thymic lobe chains were located in the distal third of the ventral region of the neck and were arranged linearly and parallel from the eleventh to the fifteenth cervical vertebra relating to the vagus nerve and jugular vein. The number of lobes ranged from one to three and one or two for the right and left antimeres, respectively. The mean dimensions of the lobes in length, width and thickness were: $2.09 \times$ $0.71 \times 0.41 \mathrm{~cm}$ for the cranial lobe; $0.69 \times 0.38 \times 0.27 \mathrm{~cm}$ for the middle lobe; and $0.55 \times 0.33 \times 0.29 \mathrm{~cm}$ for the caudal lobe of the right antimere. In the left antimere, the dimensions were $2.14 \times 0.71 \times 0.37 \mathrm{~cm}$ for the cranial lobe and $0.60 \times 0.31 \times 0.22 \mathrm{~cm}$ for the caudal lobe.

According to Ciriaco et al. (2003), the thymus of birds remains active for a longer period of time than in mammals, but information about the changes that occur with the thymus during the ontogeny of the animal is still scarce and incomplete.

Exploration and establishment of the anatomical and physiological parameters of animals currently used for poultry production is of paramount importance for our understanding of why these species are best adapted to existing breeding conditions. The objective of this research is to contribute to the knowledge of morphological and biometric aspects of the thymus in birds of the Isa Brown strain. Knowledge of the anatomical patterns in birds with high egg production may aid in the selection of specimens presenting lymphoid organ shapes and sizes that are best suited to perform body functions efficiently.

\section{MATERIALS AND METHODS}

The methods from this project were submitted to analysis by the Ethics Committee for the Use of Animals at the University of Rio Verde. Our methods were approved under protocol CEUA/UniRV Nº 012/16.

Thirty chickens (Gallus gallus domesticus) of the Isa Brow line aged approximately ninety-three weeks old and weighing approximately $1953.1 \mathrm{~g}$ were obtained from the Federal Institute of the Triângulo Mineiro, Uberlândia, Minas Gerais. The birds were euthanized in the Animal Anatomy Laboratory of the University of Rio Verde using the standard anesthesia protocol suggested by Rosskopf; Woerpel (1996), which consists of the use of $10 \%$ anesthetic gas overdose (Halotane, Cristália Produtos Químicos e Farmacêuticos Ltda.) for three minutes, which is the protocol also recommended by the Brazilian College of Animal Experimentation.

Immediately after death, the body mass of each animal was determined using an electronic and counting scale (Digitron $囚$ ). Following to the guidelines of Rodrigues (2010), specimens were fixed in $10 \%$ formalin aqueous solution (Labsynth - Produtos para Laboratório Ltda.) by subcutaneous, deep intramuscular and intracavitary injection. Soon after, the body parts were immersed in the same solution for preservation.

After a minimum period of one week, which is recommended for effective penetration of the formalin solution into the tissues of the animal (RODRIGUES, 2010), the necessary dissections were performed using a scalpel, blades, scissors and anatomical tweezers. The region occupied by the thymus was exposed through a median ventral incision of the cervical region followed by subcutaneous connective tissue divulsion. In this way, the right and left cervical lobes were identified and, through a section of the pectoral muscles and the clavicular bones (the coracoid and the sternum), the entire set of structures of the chest wall was collapsed caudally to verify the presence of thymus in the thoracoabdominal cavity.

Measurements of each thymic lobe were taken using a digital caliper (Starret $($ ), with the following dimensions being determined: length, taking the craniocaudal axis measurement; width, using the measurement of the dorsoventral axis; and thickness, evaluating the measurement of the laterolateral axis.

The location of the thymus, its relation to the skeleton and with neighboring structures, and parts of the organ itself were described to characterize the holotopia, skeletopia, syntopia and idiotopia. 
Photographic records were taken and schemes of all preparations were made for archiving and publication. The anatomical terms used are based on Nomina Anatomica Avium (BAUMEL, 1993).

\section{RESULTS}

The mean body mass of the bird was 1,808 to $2,060 \mathrm{~g}$, with a median of $1,953.1 \mathrm{~g}$ and standard deviation of 87.04. The thymus lobes were located along the entire ventral region of the neck, arranged linearly and parallel to the opposite antimere. The cranial portion of each chain gradually moved away from the median plane as it approached the cranial third of the neck, becoming laterally disposed, while the middle and caudal portions were positioned medially.
For the skeletopia, which deals with the relationship between the bones and the thymus, the latter assumes a relation that extends from the third cervical vertebra to the transition between the last cervical vertebra and the first thoracic vertebra, approaching the caudal limit of the clavicular bones and the cranial limit of the mandibular bones.

The visceral static of the thymus is maintained by the structures that are part of the relation of syntopia: adipose and connective tissues that surround the structures adjacent to the organ; the common artery of the vagus nerve that, sending its branches for nutrition of the thymic parenchyma, forms an anchorage system; and the jugular vein and the vagus nerve that act in the same way as the artery (Figure 1).

Figure 1 - Right lateral region of Gallus gallus domesticus (Isa Brow strain) showing the relation of topography of the thymic lobes (A) with the common artery of the right vagus nerve (B), the right jugular vein (C), the right vagus nerve (D), adipose tissue (E), the trachea (F) and the esophagus $(G)$.

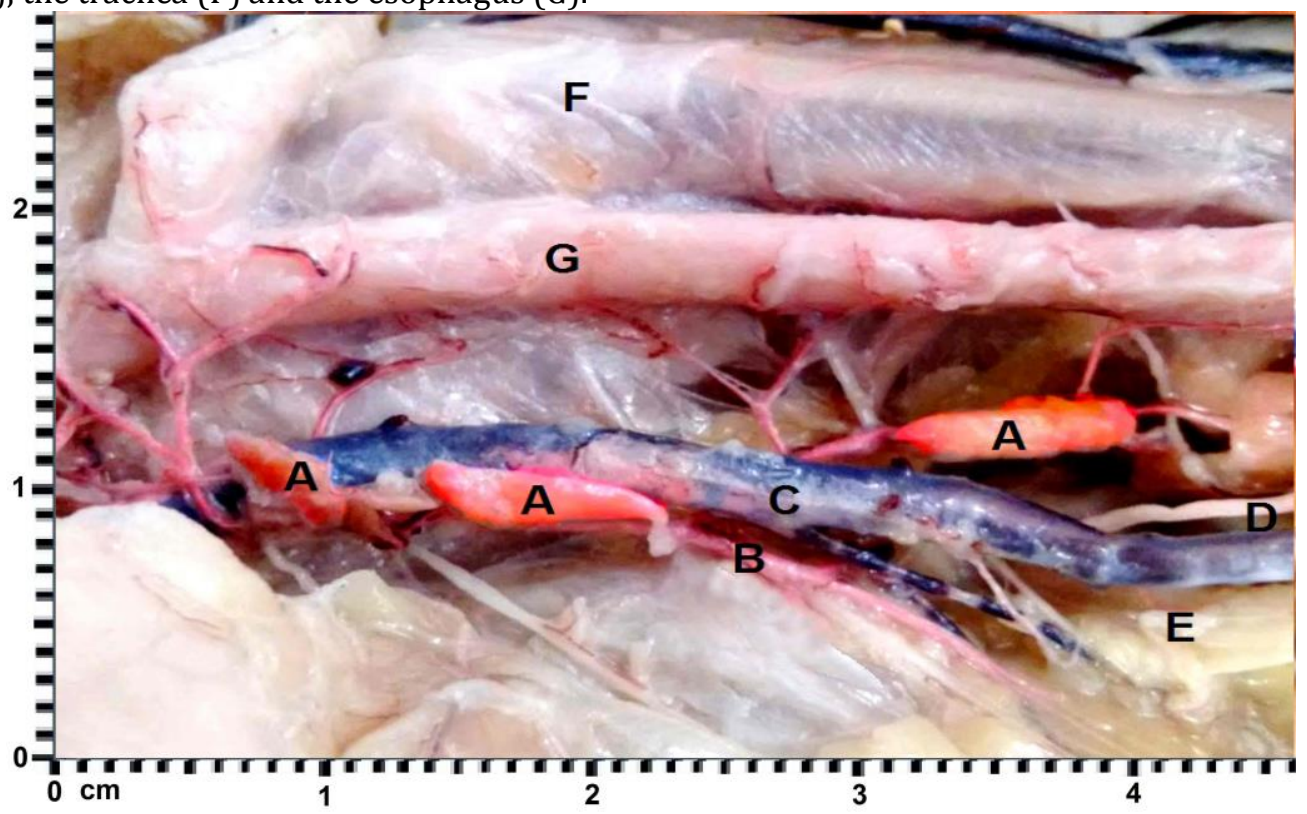

Source: Author's collection.

The thymic lobes were isolated after the removal of connective and adipose tissue with small superficial fissures, where eventually the penetration of arterial and nervous branches occurred and they escaped the venous tributaries. Through the removal of adipose tissue, four thymic lobes were found in 18 individuals (60\%) and 5 lobes were found in 12 individuals (40\%) in the right antimere. For the left antimer, 3 lobes were found in 8 individuals (26.66\%); 4 in 16 individuals (53.33\%); and 5 thymic lobes in another 6 individuals (20\%). The mean number of lobes for the right and left antimeres was 4.4 and 3.93 , respectively.

In the 30 studied birds, the presence of thymic lobes in the thoracoabdominal cavity or any connection of its parenchyma with the thyroid gland was not identified. The mean length, width, and thickness of the right antimere lobes of animals having 4 lobes was: $0.79 \mathrm{x}$ $0.41 \times 0.37 \mathrm{~cm}$ for the cranial lobe; $1.45 \times 0.81 \times 0.48 \mathrm{~cm}$ for the middle cranial lobe; $2.29 \times 0.91 \times 0.57 \mathrm{~cm}$ for the middle caudal lobe; and $3.86 \times 1.40 \times 1.09 \mathrm{~cm}$ for the caudal lobe. For the animals that presented 5 lobes, the average measurements were $0.82 \times 0.45 \times 0.40 \mathrm{~cm}$ for the cranial lobe; $1.66 \times 0.82 \times 0.46 \mathrm{~cm}$ for the middle cranial lobe; $2.10 \times 0.64 \times 0.46 \mathrm{~cm}$ for the middle lobe; $2.30 \times 0.85 \times 0.63 \mathrm{~cm}$ for the middle caudal lobe; and $3.77 \times 1.37 \times 1.14 \mathrm{~cm}$ for the caudal lobe.

The dimensions of the left antimere lobes for animals presenting 3 lobes were: $0.82 \times 0.41 \times 0.37 \mathrm{~cm}$ for the cranial lobe; $2.48 \times 0.94 \times 0.60 \mathrm{~cm}$ for the middle lobe; $3.91 \times 1.46 \times 1.06 \mathrm{~cm}$ for the caudal lobe. For animals that presented 4 lobes, the measurements were: $0.78 \mathrm{x}$ $0.41 \times 0.37 \mathrm{~cm}$ for the cranial lobe; $1.55 \times 0.78 \times 0.44 \mathrm{~cm}$ 
for the middle cranial lobe; $2.38 \times 0.85 \times 0.6 \mathrm{~cm}$ for the middle caudal lobe; $3.81 \times 1.35 \times 1.08 \mathrm{~cm}$ for the caudal lobe. For animals that presented 5 lobes, the measurements were: $0.75 \times 0.41 \times 0.35 \mathrm{~cm}$ for the cranial lobe; $1.40 \times 0.73 \times 0.43 \mathrm{~cm}$ for the middle cranial lobe; $1.86 \times 0.61 \times 0.43 \mathrm{~cm}$ for the middle lobe; $2.32 \times$ $0.65 \times 0.55 \mathrm{~cm}$ for the middle caudal lobe; $3.74 \times 1.29 \mathrm{x}$ $1.03 \mathrm{~cm}$ for the caudal lobe.

\section{DISCUSSION}

Schwarze; Schröder (1972), Nickel; Schummer; Seiferle (1977), Kendall (1980), Getty (1986), Baumel (1993), Santana et al. (2000, 2001, 2004, 2007, 2008), Silva et al. (2001), Lima et al. (2004, 2009, 2013), Pereira et al. (2008), Birck et al. (2008), Miranda et al. (2008), Arantes et al. (2011), Resende et al. (2012) and Vianna et al. (2012) are unanimous in describing the chains of thymic lobes occupying the distal third of the ventrolateral region of the neck, forming a chain of lobes that are arranged in a linear and parallel fashion, corroborating the holotopia of the thymus of the animals analyzed in this study. Regarding the location of the thymus, Santana et al. (2001) and Lima et al. (2009; 2013) reported the presence of thymic lobes within the thoracoabdominal cavity, which did not occur in this study.

Some authors describe the skeletal system of the thymus as cited by Santana et al. (2008), who established the mandible as the cranial limit and the clavicle as the caudal limit. Pereira et al. (2008) and Arantes et al. (2011) do so incompletely, citing only the cranial relationship from the first or third cervical vertebrae, respectively. Lima et al. (2004) only mention the caudal limit relating to the clavicle. This relationship with the skeleton is detailed in this work, with similarities to that described by Santana et al. (2008). For birds of the Isa Brow line, it occurs from the third cervical vertebra to the proximity to the clavicle, delimiting the place occupied by the thymus with reference to the bones of the cervical region, which could facilitate palpation of the organ in the exact region of its occurrence.

Schwarze; Schröder (1972), Nickel; Schummer; Seiferle (1977), Kendall (1980), Getty (1986), Baumel (1993), Santana et al. (2007), Birck et al. (2008) and Arantes et al. (2011) mention the relation of the thymus to the vascular-nervous bundle; however, they do not describe the structures that form this bundle. The relation of syntopia in specimens from the present work is described in detail, and the structures that are part of this bundle are also related: the common artery of the vagus nerve, the jugular vein, and the common artery of the vagus nerve for the two antimeres. Authors such as Lima et al. (2004) and Santana et al. $(2004,2008)$ refer to a vascular-nervous plexus, terminology that could perhaps be consecrated by use, but which today is at odds with the nomenclature proposed by Baumel (1993). The relations of the thymus with the vagus nerve and jugular vein, or with the common artery of the vagus nerve and jugular vein, or the vagus nerve, jugular vein and common artery of the vagus nerve are cited by Pereira et al. (2008, 2016), Miranda et al. (2008) and Resende et al. (2012), respectively.

Schwarze; Schröder (1972), Nickel; Schummer; Seiferle (1977), Kendall (1980), Getty (1986) and Baumel (1993) reported that in young birds, the thymus is not divided into lobes. This was not observed in birds in the current study because they were all adults aged approximately ninety-three weeks old. We emphasize here the findings of Pereira et al. (2016) stating that young ostriches have clearly individual thymic lobes.

The number of lobes, which in this study ranged from 3 or 4 in the right antimere and 3 to 5 in the left, should be considered as a reduced number and similar to those reported by Birck et al. (2008) in birds of the Cobb 500 strain, Resende et al. (2012), in mussels, Lima et al. (2013) in macaws, and Santana; Netto; Silva. (2004) in the curassow, in which the authors found 3 to 5 lobes, 2 to 5,5 , and 6 lobes per antimere, respectively. We highlight that the birds analyzed by the last three authors were wild, and those studied by the former were genetically prepared birds for posture, similar to those in the present research. It can be observed that, in relation to the number of lobes, the thymus of birds from the Isa Brow line resembles that of wild species and lineages of laying hens. Hohn (1947) also stated that the thymus of domestic ducks and geese present characteristics similar to those of the wild species in which few lobes occur (generally 5), which also agrees with data from the present study.

As for syntopia with the thyroid gland, it can be affirmed that there was no direct contact between these structures, contrary to what was affirmed by Getty (1986), Silva et al. (2001), Lima et al. (2009) and Arantes et al. (2011) when describe that the thymic tissue can be invaded by the thyroid gland. Morphometric data for the thymus were described by Santana et al. (2007), Lima et al. (2013) and Pereira et al. (2016). The former dealt only with length and width and the latter two, as in this research, took measurements of length, width and thickness. The dimensions observed in the present study are larger than those found by other authors. However, it should be noted that the number of lobes found by Santana et al. (2007) for Angolan hens reached 22; therefore, they have a larger number of smaller lobes whereas in the birds of the Isa Brow line, there are fewer lobes (from 3 to 5) with larger dimensions. Lima et al. (2013) described the thymus of macaws and in terms of body mass, results from that study justify the reduced dimensions found. Pereira et al. (2016) studied ostrich pups, and because of their large size, those results corroborate the similarities in measurements found between that study and birds in the current study, which were adults. 
Baumel (1993), Lima; Santana; Dos Reis (2004), Santana et al. $(2007,2008)$ and Arantes $(2011)$ reported that the position occupied by thymic lobes and their size are variable, as shown also in ostriches by Pereira et al. (2016). This relation of the holotopia also occurred in birds of the Isa Brow line, in which the caudal lobes are always larger than the previous ones and occupy a dorsolateral position in relation to the cranial lobes, which tend to occupy the ventrolateral position in relation to the vascular-nervous plexus; this corroborates reports by Santana et al. (2008).

\section{CONCLUSIONS}

Several thymic characteristics found in this research, such as lobe division and topography are similar to those characteristics found by other authors. However, skeletal, syntopic and holotopic data show unique characteristics in birds of the Isa Brow lineage. The morphological and biometric parameters of the thymus present well-defined behaviors with both common and different characteristics compared to other poultry strains. Lobe size may be useful in creating morphological and morphometric models that may guide the selection of other lineages for the production of eggs, with the goal of achieving the high productive capacity of the Isa Brown lineage.

\section{ACKNOWLEDGEMENTS}

We are grateful to the University of Rio Verde - UniRV for technical and financial support to execute the project.

\section{REFERENCES}

ARANTES, R. C. et al. Vascularização arterial do timo em galinha caipira (Gallus gallus). PUBVET, Londrina, v. 5, n. 14, p. 1-15, 2011.

BAUMEL, J. J. Handbook of avian anatomy: Nomina Anatomica Avium. 2 ed. Cambridge: Nuttall Ornithological Club, 1993. 779 p.

BIRCK, A. J. et al. Suprimento arterial do timo de aves (Gallus gallus) da linhagem cobb 500. Revista Científica Eletrônica de Medicina Veterinária, Garça, v. 6, n. 11, p. 30-37, 2008.

CIRIACO, E. et al. Age-Related Changes in the Avian Primary Lymphoid Organs (Thymus and Bursa of Fabricius). Microscopy research and technique. V 62, p. 482-487, 2003.

GETTY, R. Sisson/Grossman anatomia dos animais domésticos. 5 ed. Rio de Janeiro: Guanabara Koogan, 1986. 2048 p.

HOHN, E. O. Seasonal cyclical changes in the thymus of the Mallard. Journal Experimental Biology, Cambridge, v. 24, p. 184-191, 1947.

KENDALL, M. D. Avian thymus gland. Developmental and Comparative Immunology, London, v. 4, n. 1, p. 191-209, 1980.

LIMA, E. M. M. et al. Suprimento vascular arterial do timo em aves (Gallus gallus) da linhagem Máster Gris Cou Plumé. Biotemas, Florianópolis, v. 22, n. 3, p. 171-176, 2009.

LIMA, R. Z. et al. Morfologia e biometria do timo em araras dos gêneros Ara e Anodorhyncus. Arquivos Brasileiros de Medicina Veterinária e Zootecnia, Belo Horizonte, v. 26, n. 1, p. 103-111, 2013.
LIMA, R. Z.; SANTANA, M. I.; DOS REIS, I. A. Morfologia e vascularização do timo em patos (Anas platyrhynchus). In: REUNIÃO DE INTEGRAÇÃO DA MORFOLOGIA PAN-AMERICANA/CONGRESSO BRASILEIRO DE ANATOMIA, 8/XXI, 2004, Foz do Iguaçu. Anais... Foz do Iguaçu: UFPR, 2004. p. 12.

MARÍN, F. P.; NAVA, J.; MAVÁREZ, Y. Caracterización morfométrica de los organos linfoides en pollos de engorde de la línea Ross criados bajo condiciones de campo en el estado Zulia, Venezuela. Revista Científica, Maracaibo, v. 14, p. 217-225, 2004.

MENDES, A. A.; MOREIRA, J. Produção e características das linhagens de corte. In: MACARI, M.; MENDES, A. A. Manejo de matrizes de corte. 2. ed. Campinas: FACTA, 2005. Cap. 1, p. 1-10.

MIRANDA, R. L. et al. Artéria do timo em aves (Gallus gallus) poedeiras da linhagem Bovans Goldline. Bioscience Journal, Uberlândia, v. 24, n. 4, p. 138-142, 2008.

NICKEL, R.; SCHUMMER, A.; SEIFERLE, E. Anatomy of the domestic birds. Berlin: Verlag Paul Parey, 1977.202 p.

PEREIRA, C. C. H. et al. Irrigação arterial do timo em aves (Gallus gallus domesticus) da linhagem Hubbard. Veterinária Notícias, Uberlândia, v. 14 , n. 1, p. 41-47, 2008.

PEREIRA, C. C. H. et al. Morfologia e biometria do timo em avestruzes (Struthio camelus). Biotemas, Florianópolis, v. 20, n. 2, p. 59-68, 2016.

RESENDE, G. G. N. et al. Suprimento vascular arterial do timo de marrecos (Anas platyrhynchos platyrhynchos). Revista Cientíica Eletrônica de Medicina Veterinária, Garça, v. 9, n. 18, p. 1-10, 2012.

RODRIGUES, H. Técnicas Anatômicas. 4. ed. Vitória: GM gráfica e editora, 2010.

ROSSKOPF, W.; WOERPEL, R. Diseases of cage and aviary birds.3.ed. New York: Willians \& Nilkins, 1996. p.84-86.

SANTANA, M. I. S. et al. Irrigação do timo em aves da linhagem Paraíso Pedrês (Gallus gallus). Arquivos Brasileiros de Medicina Veterinária e Zootecnia, São Paulo, v. 60, n. 2, p. 307-314, 2008.

SANTANA, M. I. S. et al. Morfologia e morfometria do timo em galinhas de Angola (Numidea meleagris galeata). Revista Portuguesa de Ciências Veterinárias, Lisboa, v. 102, n. 561-562, p. 43-48, 2007.

SANTANA, M. I. S. et al. Vascularização arterial do timo em aves (Gallus gallus domesticus) da linhagem NPK. Veterinária Notícias, Uberlândia, v. 7, n. 1, p. 13-19, 2001.

SANTANA, M. I. S. et al. Vascularização arterial do timo em aves (Gallus gallus domesticus) da linhagem Avian Farms. Bioscience Journal, Uberlândia, v. 16, n. 2, p. 3-15, 2000.

SANTANA, M. I. S.; NETTO, A. P.; SILVA, F. O. C. Morfologia e irrigação do timo em mutuns (Crax fasciolata). In: REUNIÃO DE INTEGRAÇÃO DA MORFOLOGIA PAN-AMERICANA/CONGRESSO BRASILEIRO DE ANATOMIA, 8/XXI, 2004, Foz do Iguaçu. Anais... Foz do Iguaçu: UFPR, 2004. p.14.

SCHWARZE, E.; SCHRÖDER, L. Compêndio de anatomia veterinária. Vol. 5. Zaragoza: Acribia, 1972. 212 p.

SILVA, F. O. C. et al. Artérias do timo de aves (Gallus gallus) da linhagem Label Rouge. Bioscience Journal, Uberlândia, v. 17 n. 2, p. 115-123, 2001.

VIANNA, A. R. da C. B. et al. Macroscopic morphology and arterialvascular supply of thymus in fowls (Gallus gallus domesticus) of Red Bro Cou Nu lineage. Acta Scientiarum, Maringá, v. 34, n. 4, p. 457462, 2012. 